\title{
Histopathological changes induced by methotrexate in bone and bone marrow of male and female white mice
}

\author{
K. G. Chelab \\ Coll. Vet. Med. Unive.of Al Qadisiya \\ S. Kh. Majeed \\ Coll. Vet. Med./Unive.of Al Basrah
}

\begin{abstract}
The present study was conducted on 40 females and males white mice of approximately the same ages (4-6 weeks) and body weights (23-25 gm), for the aim of observing the toxic effects and histopathological changes on bones of mice due to prolonged treatment (6 months) with anticancer chemotherapeutic agents namely methotrexate. Forty mice were divided into 4 equal groups ( 10 mice of each group -5 mice per sex). The first group (low or therapeutic dose group) was received $0.15 \mathrm{mg} / \mathrm{kg}$, I/M once weekly. The second group (intermediate dose group) received $0.30 \mathrm{mg} / \mathrm{kg}, \mathrm{I} / \mathrm{M}$ once weekly. The third (toxic dose group) received $0.45 \mathrm{mg} / \mathrm{kg} \mathrm{I} / \mathrm{M}$ once weekly. The fourth group was a control group, it received $0.2 \mathrm{ml}$ buffered normal saline, I/M once weekly.The results showed Methotrexate can cause osteoporosis and bone marrow suppression, due to cytotoxic effects of it on bone marrow.
\end{abstract}

\section{Introduction}

For the last 40 years, chemotherapy has had a role in cancer management in human and animal patients. More than 50 agents are useful in human medicine (1), but the number of the partial use in veterinary medicine is less common.Chemotherapy may help control generalized rapidly progressive not amenable to surgery or radiotherapy or may help increase the disease - Free interval after other initial treatment. It may prevent spread of a neoplasm by controlling early metastases that are proliferating rapidly and have a relatively small likelihood of containing resistant cells (2).Chemotherapeutic protocols are most often limited by host toxicoses. Recalling one of the biological bases of chemotherapy that proliferating neoplastic cells can be attacked most effectively as they pass around the cell cycle and helps explain some of the more commonly noted toxicoses related to rapidly renewing tissue. The most commonly encountered problems relate to gastrointestinal toxicity, bone marrow suppression, and immunosuppressant (3). The main problem in cancer chemotherapy is the lack of

\section{Materials and methods}

Forty mice (20 males and 20 females) of 1-1.5 months old were divided into four equal groups (each groups consisted of five males and five females). highly selectively toxic agents. Cancer cells arise from normal cells and, unlike the situations described for viral, bacterial and fungal infections, there is a paucity of obvious selective drugs targets. With currently used antiproliferative anticancer drugs, many rapidly dividing normal cells (bone marrow, gut epithelium, spermatogenetic cells, lymphoid tissue, hair follicles, and fetus) are damage or destruction (4).Chemotherapy involves the use of one or several antineoplastic (anticancer) drugs affect on cancer cells. Methotrexate is an example of an anticancer drug that interferes with cellular reproduction and is also used in the treatment of psoriasis and certain inflammatory disease (5). Methotrexate is a chemical agent that acts by inhibiting the enzyme dihydrofolic acid reductase, which catalyses the conversion of folic acid to its active form folinic acid, by binding to it (6).This study was designed to investigate side effects of methotrexate on bones in white mice because methotrexate has been use in various fields of oncology for along time, and also it was use for other diseases such as psoriasis and rheumatoid arthritis.

The animals were housed in a $6 \times 4 \times 3 \mathrm{~m} 3$ room in animal house of Veterinary Medicine College, Baghdad University under 12 hours light / 12 hours dark at $21 \pm$ 
$4{ }^{\circ} \mathrm{C}$ and put as 5 mice in each standard plastic cage.

\section{Treatment}

Methotrexate (Trixilem) ${ }^{\circledR}$ is a drug that is used to treat certain cancers. With methotrexate, cancer cells can not make DNA; this kills cancer cells and it is a clear yellowish solution, vial of $5 \mathrm{mg} / 2 \mathrm{ml}$ for injection, (lemery-Uppsala Sweden). Each $5 \mathrm{mg} / 2 \mathrm{ml}$ was diluted with $333 \mathrm{ml}$ physiological normal saline and the mixture was injected intramuscularly to animals. Animals were injected once weekly and for six months, untreated controls received equivalent amount of physiological normal saline.

\section{Experimental Design}

Forty mice divided into for four equal groups: First group as a therapeutic (low

dose) received $0.15 \mathrm{mg} / \mathrm{kg}$, intramuscularly once weekly diluted with $0.2 \mathrm{ml}$ saline. Second group as intermediate dose received $0.30 \mathrm{mg} / \mathrm{kg}$, intramuscularly once weekly diluted with $0.2 \mathrm{ml}$ saline. Third group received a high dose (toxic dose) $0.45 \mathrm{mg} / \mathrm{kg}$, intramuscularly once weekly. Fourth group is a control group received only normal saline at a dose of $0.2 \mathrm{ml}$ intramuscularly once weekly

For histopathology, the femurs bones of mice were taken and kept in formic acid for three days for decalcification, processed routinely in histokinette, cut at 5 Mm thickness by microtome (Jung 4291, West Germany) and stained with Haematoxyline and Eosin stain then examined under light microscope (7).

\section{Results}

\section{Macroscopic changes}

The bone (femoral bone) was thin and easy to broken in all treated groups especially in toxic dose group.

Microscopic changes:

Control Group: There were no significant microscopic signs in control untreated animals.

Low or Therapeutic dose group: The bone showed minimal suppression to bone

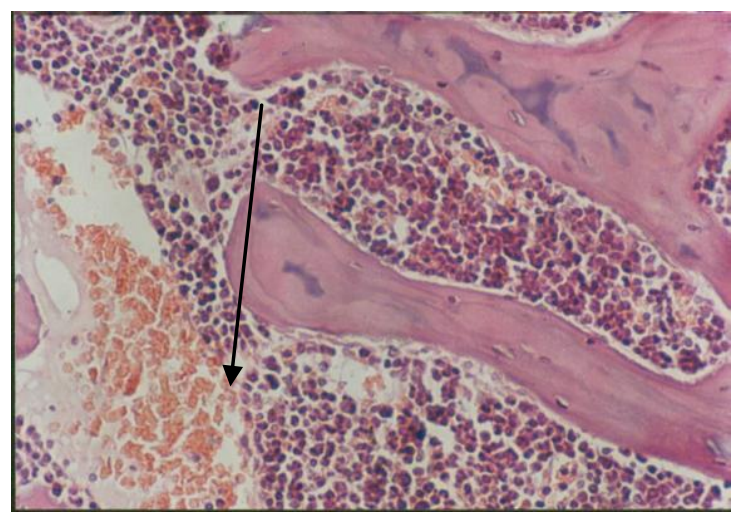

Figure (1): spongy bone (low dose group): show minimal suppression to bone marrow cells with evidence of decrease in numbers of osteocytes congestion of bone marrow (arrows). 50X H\&E. marrow cells with evidence of decrease in numbers of osteocytes. (Figure 1).

Intermediate dose group: The bone showed evidence of decrease in numbers and necrosis of osteocytes with congestion of bone marrow (Figure 2), (Figure 3).

Heavy or Toxic dose group: The bone showed sever necrosis, reduction of hemopoiesis and evidence of osteoporosis with congestion of bone marrow (Figure 4).

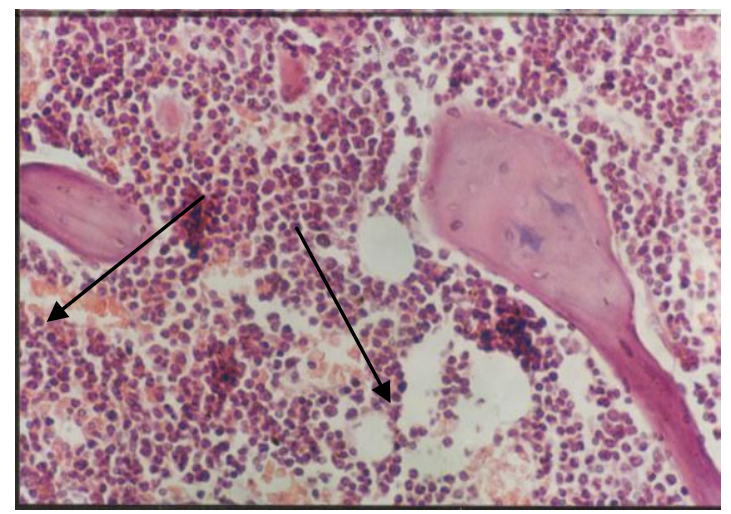

Figure (2): spongy bone (intermediate dose group): The bone showed evidence of decrease in numbers of osteocytes with congestion of bone marrow (arrows). 50X H\&E. 


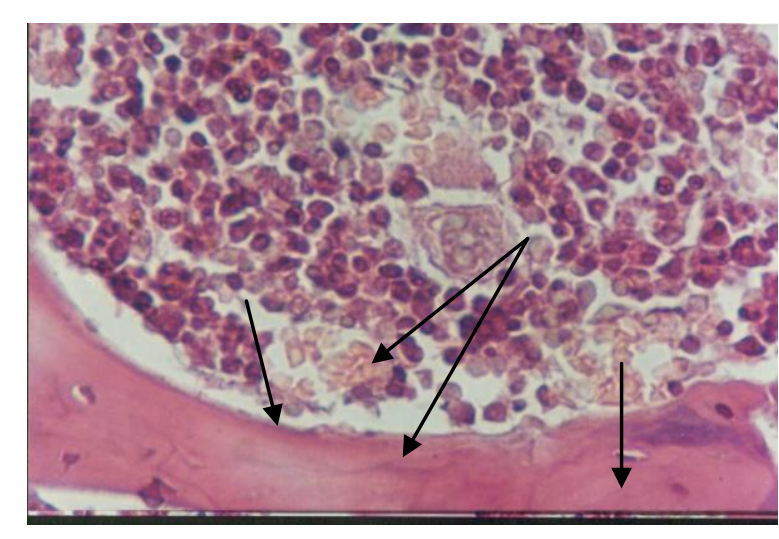

Figure (3): spongy bone (intermediate dose group): The bone showed evidence of decrease in numbers and necrosis of osteocytes (double arrows) with congestion of bone marrow (arrows). 200X H\&E.

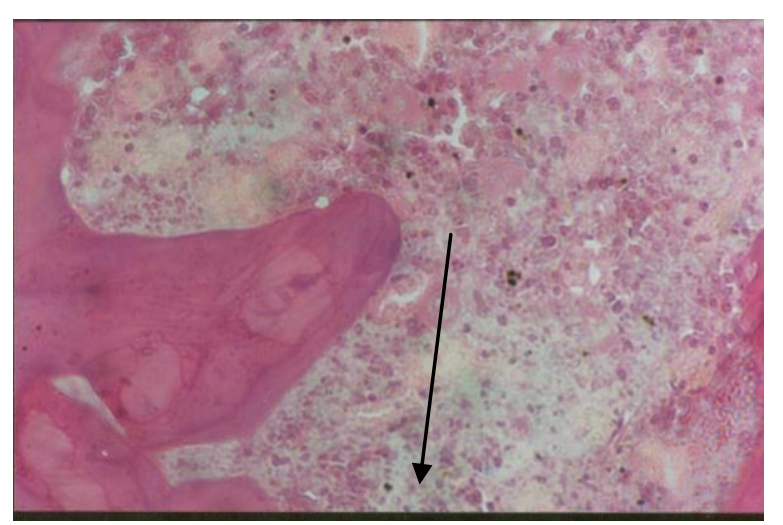

Figure (4): Spongy bone (toxic dose group): The bone showed sever necrosis (arrow), reduction of hemopoiesis and evidence of osteoporosis and congestion of bone marrow. 200X H\&E.

\section{Discussion}

Cancer occurs when cells grow too rapidly and in an uncontrolled way. For cancer cells to grow, new DNA needs to be made. Methotrexate is a drug that is used to treat certain cancers. With methotrexate, cancer cells can not make DNA; this kills cancer cells (8). However, methotrexate can also be harmful to other normal cells and organs in the body, this harmful effect is called methotrexate toxicity, using methotrexate for long period and the longer methotrexate stays in the body, can increase the risk of toxicity (9). For these reasons and others, this study had focused to investigate on effect of methotrxate on bones in mice. The bones were appeared affected in all treated animals especially in toxic dose group animals.the present study showed macroscopic and microscopic changes in bones which characterized by evidence of osteoporosis and reduction of hemopoiesis in all treated animals (low, intermediate, and toxic doses animals), the mechanism by which methotrexate causes osteoporosis is due to increased urinary and fecal calcium excretion and decreased bone formation (10) ; (11), they provided evidence that there was increased urinary and fecal calcium excretion in some cancer patients treated with methotrexate. Also (12), they indicated that there was decreased bone formation in rats treated with methotrextae.

\section{References}

1. Carter, S.K. and Livingston, R.B. (1981). Drugs available to treat cancer. In Carter, S.K.: Principles of cancer treatment. McGraw, Hill.; New York.

2. Theilin, G.H. (1987). Chemotherapy. In Theilen GH, Madewell BR. Veterinary Cancer Medicine. $2^{\text {nd }}$ Ed., Lea and Febiger, Philadelphia; PP: 1315-1318.

3. McEwen EG. (1980). Cancer chemotherapy. In Kirk RW. Current Veterinary Therapy. $7^{\text {th }}$
Ed., W. B. saunders, Philadelphia; PP: $742-745$.

4. Boulton A.J.M., Carpenter J. R., Clark B., Dascombe M.J., Deakin J.F.M., Dive C., Duxbury A.J. and Foster R.W. (1996). Antiparasitic Chemotherapy. In Basic pharmacology. $4^{\text {th }}$ Ed., Oxford Auckland Boston and Johannesburg Melbourne, New Delhi; PP: 269-274.

5. Connaughton K. (2003). Effects of dietary supplementation with RNA 
on recovery of intestinal function after administration of methotrexate. J. undergraduate Research; PP: 1-7.

6. Duran N.; Allahverdiyev A.M.; Cetiner A. (2001). Vepesid on the HEp-2 cell cycle. Turk J Med. Sci.; 31: 187-192.

7. Luna, L.G. (1968). Manual of Histological staining methods of the armed forces. Institute of Pathology. $3^{\text {rd }}$ Ed., McGraw-Hill Book Company, N. Y., Toronto. London, Sydney; 12-31.

8. Cronstein B.N.; Naime D.; Ostad E. (1993). The anti-inflammatory mechanism of methotrexate: increased adenosine release at inflamed sites diminishes leukocytes accumulation in an in vivo model of inflammation. J. Clin. Invest; 92: 2675-2682.

9. Rosenthal, G.J.; Weigand, G.W.; Germolec, D.R. (1988).
Suppression of B cell functions by methotrexate and trimethotrexate. Evidence for inhibition of purine biosynthesis as a major mechanism of action. J. Immunol.; 141: 410416.

10. Nesbit, M., Krivit, W.; Heyn, R. and Sharp, H. (1976). Acute and Chronic effects of methotrexate on hepatic, pulmonary and skeletal systems. Cancer; 37: 1048-1057.

11. Nevinny, H.B.; Krent, M.J. and Moore, E.W. (1965). Metabolic studies on the effect of methotrexate. Metabolism;14: 135-139.

12. Friedlaender, G.E.; Tross, R.B.; Doganis, A.C.; Kirkwood, J.M. and Baron, R. (1984). Effects of chemotherapeutic agents on bone. Short-term methotrexate and doxorubicin (adriamycin) treatment in a rat model. J. Bone Joint Surg.; 66: 602-607.

\section{التغيرات المرضية المحدثة بواسطة الميتوتركسات في العظم ونقي العظم لأكور وإناث القئران البيضاء المئوكيات$$
\text { كلية الطب كاظبط مجيد/جامعة البصرة }
$$ \\ الخلاصة}

